\title{
Root temperature and short term accumulation of carbohydrates in two maize hybrids at early growth stage
}

\author{
J.-S. Frossard and J.-F. Friaud \\ with the technical assistance of $B$. Saint-Joanis
}

INRA, laboratoire de bioclimatologie, domaine de Crovelle, 63039 Clermont-Ferrand, France

(received 13 December 1988, accepted 1 October 1989)

Summary - Root and shoot carbohydrate content of 14-day old maize plants of two grain types (flint and dent) was studied after $48 \mathrm{~h}$ temperature treatment of the root; shoot temperature remained constant during all the experiments. The lowering of root temperature led to carbohydrate accumulation in roots and shoots. Two-way variance analysis showed that only for the accumulation of sucrose was there any significant difference between the two hybrids for the roots. However, in the shoots, there were significant differences between genotypes for all carbohydrates. The significance level was minimum for starch; at $10^{\circ} \mathrm{C}$, accumulation in dent type was greater than that in flint type. When testing the relationship between carbohydrate accumulation; measured and non structural dry matter predicted by our model, (Frossard, 1986), there was a lack in precision due to the uncertainties surrounding the input parameters of the model. It was concluded that low root temperatures produce a complete overload of the root sinks and transfer pathways. This engorgement increases starch content in leaves, particularly in the dent genotype. The study of the effect of low root temperatures on the roots must therefore deal with the whole plant and not simply the root.

maize - genotype - seedling - short term - carbohydrates - root temperature - modelling

Résumé - Température racinaire et accumulation à court terme de glucides chez deux hybrides de maïs au stade jeune. L'étude de l'effet de la température sur l'accumulation de glucides dans les racines a été entreprise pour préciser la nature biochimique de l'accumulation de matière sèche non structurale révélée par la modélisation (Frossard, 1986) chez 2 hybrides de maïs, l'un de type denté, l'autre corné. L'abaissement de la température racinaire conduit rapidement (en 48 h) à une accumulation de glucides dans les racines et les parties aériennes. L'analyse de variance à 2 facteurs (température, génotype) permet de mettre en évidence une différence significative qui concerne: seulement le saccharose dans les racines, tous les glucides dans les parties aériennes. Les incertitudes d'entrée sur les paramètres du modèle ne permettent pas de conclure sur la nature de la matière sèche accumulée à basse température. Néanmoins les résultats acquis ne remettent pas en cause les hypothèses de base. On peut avancer que tout se passe comme si les basses températures provoquaient un engorgement complet des puits constitués par les racines et des voies de transfert; l'effet de cet engorgement se manifeste dans les feuilles (augmentation de la teneur en amidon) particulièrement pour le génotype sensible (type denté).

maïs - génotype - stade jeune - court terme - glucides - température racinaire - modélisation

\section{INTRODUCTION}

In previous studies (Frossard, 1985, 1986), it was shown that sensitivity to low root temperatures in two maize hybrids was accompanied by lower total respiration for the roots of the sensitive hybrid, lower maintenance respiration for the root system and different modes of energy use : at $10^{\circ} \mathrm{C}$ the sensitive hybrid accumulated more dry matter than the tolerant hybrid. According to our model (Frossard, 1986), this accumulation is not true growth. Does it therefore result from a particular physiological behaviour?

Various authors have shown that there was carbohydrate accumulation in plants exposed to low temperatures, e.g. in maize leaves and roots (Grobbelaar, 1963), in maize leaves (Kleinendorst \& Brouwer, 1970), in maize and pea roots 
(Crawford \& Huxter, 1977) and in maize seedlings (Bourdu, 1984). The results of Grobbelaar (1963) were obtained from 10-dayold maize, after 8 days of low temperature treatment; those of Kleinendorst \& Brouwer (1970) after a short temperature treatment but only on leaves of 8th leaf stage plants. No result concerning the short term effect of root temperature on carbohydrate accumulation in shoots and roots of maize seedlings appear to have been published. Nevertheless, we can assume that it may not be as different as those cited above.

As our previous studies have shown that the accumulation of dry matter in maize root systems at low temperature cannot be considered simply as true growth, we decided to study the effect of root temperature on carbohydrate accumulation in different parts of the plant and the relation between carbohydrates and non-structural dry matter as described by our model. As this accumulation period in the plants was short $(48 \mathrm{~h})$ relative to the duration of previous experiments (Frossard, 1985, 1986), we focused mainly on soluble carbohydrates and starch.

\section{MATERIAL AND METHODS}

\section{Plant material}

As in previous studies (Frossard, 1985) two single hybrids were used: F7xF2, flint type, tolerant to low spring temperatures in normal field cultivation conditions, and WHXWJ, dent type, chilling sensitive. The plants were grown on a well aerated nutrient solution as previously described. The temperature of the shoots and roots was $20^{\circ} \mathrm{C}$.

During temperature treatement, carried out when the plants were 14 days old, root temperatures were 10 , 15,20 (controls) and $25^{\circ} \mathrm{C}$.

\section{Carbohydrate assay}

Carbohydrate metabolism is not constant during a light-dark period $(24 \mathrm{~h})$ : root respiration has been observed with a daily rythm (Frossard, 1985). To avoid the effects of these fluctuations, samples were always taken at the same time : 30 min before the beginning of the light phase, $48 \mathrm{~h}$ after the beginning of the temperature treatment. The roots and shoots of 4 pairs of plants from each treatment were fixed in liquid nitrogen, freeze dried and ground to pass a $125-\mu \mathrm{m}$ mesh. Plant material was extracted with $80^{\circ} \mathrm{GL}$ ethanol and enzymatic assays (3 per replicate) were performed to determine starch and simple sugar content: glucose with glucose oxidase (Jourdan, 1980 ), and sucrose, first with invertase, then with glucose oxidase (Mercier \& Tollier, 1982).

The starch was autoclaved and hydrolysed with amyloglucosidase. The glucose released was assayed with glucose oxidase (Thivend, 1965 in Mercier \& Tollier, 1982). Soluble carbohydrate content was determined with the anthrone method (Halhoul \& Kleinberg, 1972; Mercier \& Tollier, 1982).

The nature of the sugar was first determined with HPLC (Agronomy Station, INRA, Clermont-FerrandTheix). The carbohydrates in the eluates were mainly glucose and sucrose, with a small amount of fructose in roots treated at $10^{\circ} \mathrm{C}$.

\section{Statistical analysis}

Having checked that the statistic distributions were Gaussian, we tested the differences between temperature treatments and genotypes with a two-way variance analysis. To give a clearer picture of the effect of temperature on carbohydrate concentration, the results were fitted to an exponential function :

$$
y(\theta)=a \cdot e^{b \theta}
$$

$y(\theta)$ carbohydrate concentration (in $g / 100 \mathrm{gDW}$ ) at temperature $\theta\left({ }^{\circ} \mathrm{C}\right) ; a$ and $b$ : coefficients (fitted by non-linear regression)

\section{Our model : a recall}

From data taken from growth analysis and respiration measurements on roots at different root temperatures (Frossard 1985, 1986), and using the definitions of growth respiration and maintenance respiration proposed elsewere (Thornley, 1970, 1977, 1982; Mc Cree, 1974; Szaniawski, 1981), we developed a model of energy use in roots (Frossard, 1986), the parameters of which are recalled in Table $\mathrm{l}$.

This model allowed us to define different situations of energy use for growth respiration $\left(R c_{r}\right)$, maintenance respiration $\left(R m_{t}\right)$, structural dry matter accumulation $\left(\Delta \mathrm{M} s_{r}\right)$ and non-structural dry matter accumulation $\left(\Delta \mathrm{M} n s_{r}\right)$, according to root temperature.

\section{Comparison of model forecasts and carbohydrate contents}

As the model did not predict the biochemical nature of the non-structural dry matter accumulated in the roots, we compared this accumulation with that of all carbohydrates (starch + sucrose + glucose + fructose).

Let $P\left(G_{r}\right)$ be the increase in carbohydrate content (relative accumulation of carbohydrates) induced by the variation in temperature as compared with controls maintained at $20^{\circ} \mathrm{C}$, and $\mathrm{P}\left(\Delta \mathrm{M} n s_{f}\right)$ the relative accumulation of non-structural dry matter predicted by the model.

With :

$$
\mathrm{P}\left(\mathrm{G}_{r}\right)_{\theta}=\left[\mathrm{G}_{r}\right]_{\theta}=\left[\mathrm{G}_{r}\right]_{20}
$$

$[\mathrm{G}]_{\theta}$ carbohydrate concentration of roots, relative to total dry matter, at temperature $\theta$.

This expression can also be written as:

$$
P\left(G_{r}\right)_{\theta}=\left(M_{r \theta} / M_{r \theta}\right)-\left(M G_{r 20} / M_{r 20}\right)
$$

$\mathrm{MG}_{r \theta}$ root total carbohydrate weight, at temperature $\theta$; $M_{r \theta}$ root total dry matter at temperature $\theta$. 
Table I. Parameters, symbols and methods of evaluation of the parameters of the model of energy use in roots (from Frossard, 1986).

\begin{tabular}{|c|c|c|}
\hline Parameter & Symbol & Methods of evaluation \\
\hline Total dry matter & $\mathrm{M}_{r}$ & Measured at all temperatures \\
\hline Total drv matter accumulation & $\Delta \mathrm{M}_{r}$ & Measured at all temperatures \\
\hline Total respiration & $\mathrm{R} t_{r}$ & Measured at all temperatures \\
\hline Maintenance respiration & $\mathrm{R} m_{r}$ & $\begin{array}{l}\text { Measured at } 20^{\circ} \mathrm{C} \\
\text { at others temperatures } \theta \text { : } \\
\mathrm{R} m_{r}=\mathrm{m}_{\theta} \mathrm{M} \\
\mathrm{m}_{\theta}=\mathrm{m}_{20} 2^{(\theta-20) / 10}\end{array}$ \\
\hline Growth respiration & $R c_{r}$ & $\begin{array}{l}\text { At all temperatures: } \\
\mathrm{R} c_{r}=\mathrm{R} t_{r}-\mathrm{R} m_{r}\end{array}$ \\
\hline Structural dry matter accumulation & $\Delta \mathrm{Ms}_{r}$ & $\begin{array}{l}\text { At } 20^{\circ} \mathrm{C}, \Delta \mathrm{M} s_{r}=\Delta \mathrm{M}_{r} \\
\text { if temperature }<20^{\circ} \mathrm{C} \text { : } \\
\Delta \mathrm{M} s_{r}=\mathrm{R} c_{r} . \mathrm{Yg}_{r} /\left(1-\mathrm{Y} g_{r}\right)\end{array}$ \\
\hline Growth efficiency & $Y g_{r}$ & $\begin{array}{l}\text { At } 20^{\circ} \mathrm{C}: \\
\mathrm{Y} g_{r}=\Delta \mathrm{M} s_{r} /\left(\Delta \mathrm{M} s_{r}+\mathrm{R} c_{r}\right) \\
\mathrm{Yg} \text { is independent of temperature }\end{array}$ \\
\hline Non-structural dry matter accumulation & $\Delta \mathrm{M} n s_{r}$ & $\begin{array}{l}\text { If temperature } \geq 20^{\circ} \mathrm{C} \text { : } \\
\Delta \mathrm{M} s_{r}=0 \\
\text { if temperature }<20^{\circ} \mathrm{C} \text { : } \\
\Delta \mathrm{M} n s_{r}=\Delta \mathrm{M}_{r}-\Delta \mathrm{Ms} s_{r}\end{array}$ \\
\hline
\end{tabular}

And:

$$
\mathrm{P}\left(\Delta \mathrm{M} n s_{r}\right)_{\theta}=\Delta \mathrm{Mns} s_{r \theta} / \mathrm{M}_{r \theta}-\Delta \mathrm{Mns} s_{r 20} / \mathrm{M}_{r 20}
$$

$\Delta \mathrm{Mns}_{r \theta}$ non-structural dry matter accumulation of roots at temperature $\theta$, calculated from the model (Frossard, 1986).

According to the hypothesis of the model of energy use in the roots (Frossard, 1986), $\Delta M n s_{r \theta}=0$ if $\theta \geq 20^{\circ} \mathrm{C}$. Thus $\Delta \mathrm{Mns} s_{r 20}=0$.

$$
\mathrm{P}\left(\Delta \mathrm{M} n s_{r}\right)_{\theta}=\Delta \mathrm{M} n s_{r \theta} / \mathrm{M}_{r \theta}
$$

\section{RESULTS AND DISCUSSION}

\section{Effect of root temperature on the accumulation of carbohydrates in the roots}

Low root temperature induced carbohydrate accumulation in the roots (Fig. 1).

Starch content, which was already low in controls (at $20^{\circ} \mathrm{C}$ ), was not modified by the temperature change but was different for the two genotypes (Table II).

The effect of temperature on the accumulation of soluble carbohydrates was similar in both hybrids. The pattern of variation of this accumulation can be reduced to an exponential function (Table III). In WHxWJ, a hybrid sensitive to low temperatures, the accumulation was always lower than that in F7xF2, a tolerant hydrid, irrespective of the chemical nature of the carbohydrate analysed (Fig. 1).

However, a two-way variance analysis showed that only the accumulation of sucrose was significantly different for the two hybrids (Table II). The tolerant hybrid had the highest respiration rate at $10^{\circ} \mathrm{C}$ (Frossard, 1985) and the greatest respiratory substrate concentration. This result is consistent with others obtained elsewhere: on tomato, in the range of values recorded, respiratory activity at $10^{\circ} \mathrm{C}$ was almost independent of carbohydrate content (Gary, 1988). The hypothesis of an accumulation of carbohydrates, as induced by a low level of respiration, at low temperature, is not tenable.

\section{Effect of root temperature on carbohydrate accumulation in shoots}

A reduction in root temperature produced an accumulation of carbohydrates in the shoots 

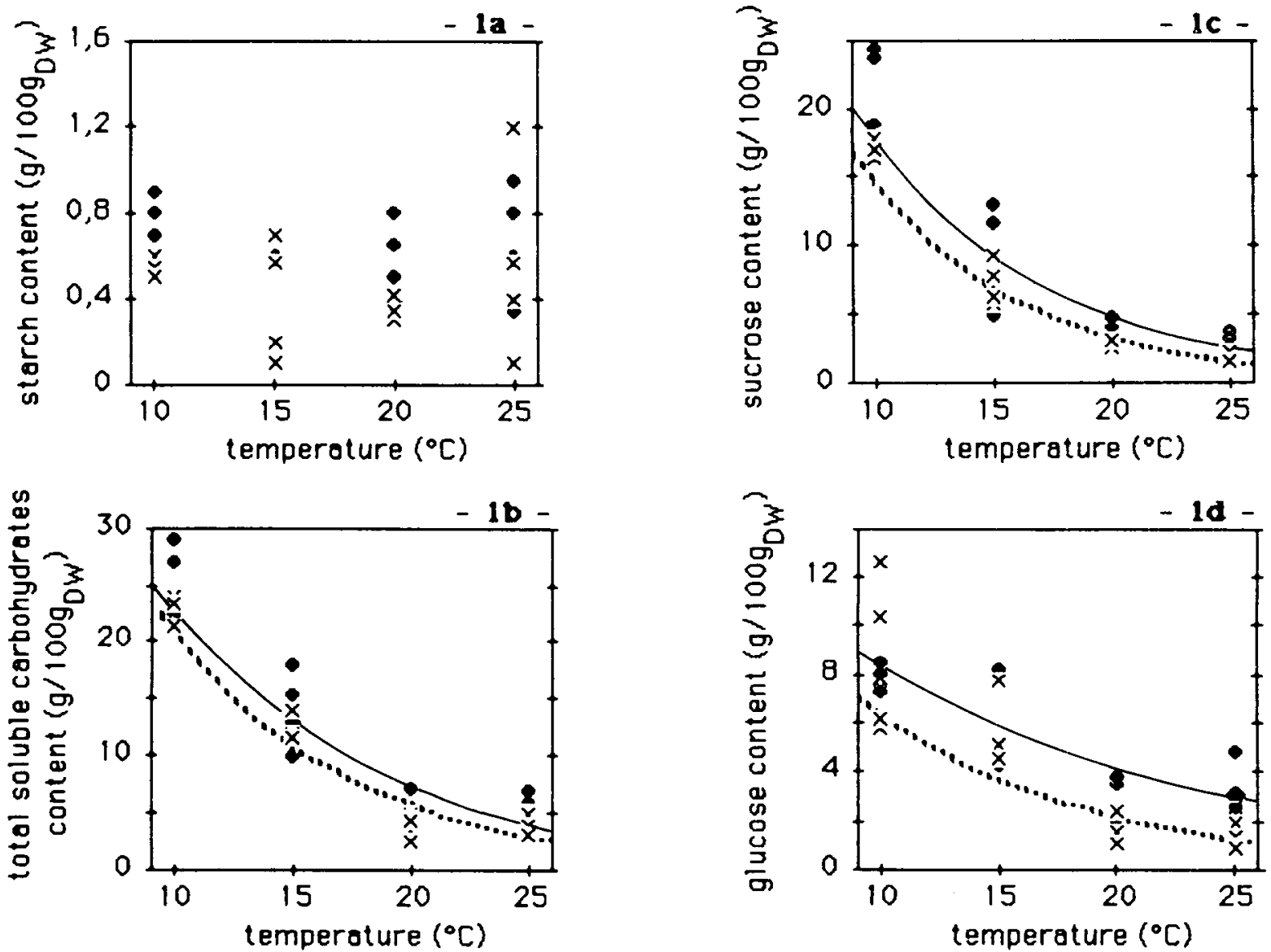

Fig. 1. Root carbohydrate content versus root temperature (for each point, 4 replicates and 3 independent assays per replicate). 1a : starch; 1b : total soluble carbohydrates; $1 \mathrm{c}$ : sucrose; 1d : glucose. $\longrightarrow$ F7xF2; $\mathrm{x} \ldots . . . \times$ WHXWJ.

(Fig. 2) similar to that observed in other species (Gary, 1988). The variation of this accumulation can also be fitted to an exponential function (Table IV). The two-way variance analysis (Table II) showed that, except for sucrose, there were significant differences between genotypes. The significance level was minimum for starch; at $10^{\circ} \mathrm{C}$, accumulation in $\mathrm{WH} \times \mathrm{WJ}$ was greater than that in F7xF2.

During the period of temperature treatment, the net assimilation rate was not modified by the lowering of root temperature (Frossard, 1985). Prioul (1984) observed that shoot to root transfers in maize were not very sensitive to temperature; hence it is unlikely that transfer would be impaired by a $10^{\circ} \mathrm{C}$ temperature. It is possible therefore that the slowing down of root respiration caused by lowering of the temperature, which results in a decrease in the carbohydrate utilization, also affects the shoots. In other words, the carbohydrate requirements of the root sinks would be sufficiently affected by

Table II. The significance levels (two-way variance analysis) of genotype and temperature effects on carbohydrate content. $n s=$ non significant $(\alpha>0.10)$.

\section{Carbohydrate}

Effect Starch $\quad$ S. carboh. Sucrose Glucose

$\begin{array}{llcccc}\text { Roots } & \text { Genotype } & 0.06 & \mathrm{~ns} & 0.04 & \mathrm{~ns} \\ & \text { temperature } & \mathrm{ns} & <0.001 & <0.001 & <0.001 \\ & \text { interaction } & \mathrm{ns} & \mathrm{ns} & \mathrm{ns} & \mathrm{ns} \\ \text { Shoot } & \text { Genotype } & 0.03 & 0.06 & \mathrm{~ns} & 0.06 \\ & \text { temperature } & <0.001 & <0.001 & <0.001 & <0.001 \\ & \text { interaction } & 0.07 & \mathrm{~ns} & \mathrm{~ns} & \mathrm{~ns}\end{array}$


Table III. Fitting of root carbohydrate content versus root temperature to an exponential function. $y(\theta)=a \cdot e^{b \theta}$, for the two hybrids ( $n c=$ non-calculable fittings).

\begin{tabular}{llccc}
\hline Genotype & $\begin{array}{l}\text { Carbo- } \\
\text { hydrate }\end{array}$ & $a$ & $b$ & $R^{2}$ \\
\hline F7×F2 & starch & nc & nc & nc \\
& s. carboh. & 68.0 & -0.13 & 0.76 \\
& sucrose & 66.0 & -0.13 & 0.86 \\
& glucose & 16.7 & -0.07 & 0.63 \\
WHXWJ & starch & nc & nc & nc \\
& s. carboh. & 75.9 & -0.13 & 0.84 \\
& sucrose & 64.7 & -0.15 & 0.94 \\
& glucose & 19.1 & -0.11 & 0.55 \\
\hline
\end{tabular}

temperature to produce an accumulation of photosynthates not used in the leaves, as observed previously (Moldau \& Sober, 1981) in similar conditions.

\section{Accumulation of carbohydrates and mode- lization of energy use in the roots}

Did carbohydrate accumulation at low temperatures really correspond to an accumulation of
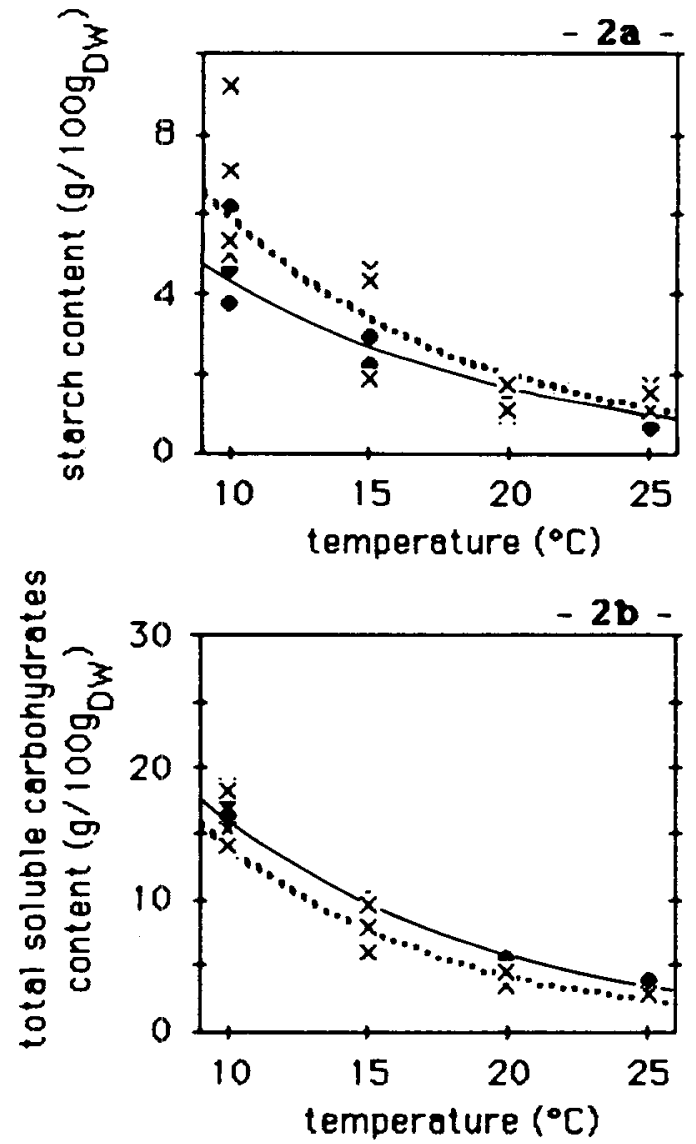

Fig. 2. Shoot carbohydrate content versus root temperature (for each point, 4 replicates and 3 independent assays per replicate). 2a: starch; 2 b: total soluble carbohydrates; $2 \mathrm{c}$ : sucrose; $2 \mathrm{~d}$ : glucose.
Table IV. Fitting of shoot carbohydrate content versus root temperature to an exponential function, $y(\theta)=a \cdot e^{b \theta}$, for the two hybrids.

\begin{tabular}{llccc}
\hline Genotype & $\begin{array}{l}\text { Carbo- } \\
\text { hydrate }\end{array}$ & $a$ & $b$ & $R^{2}$ \\
\hline F7xF2 & starch & 11.6 & -0.10 & 0.83 \\
& s. carboh. & 43.4 & -0.10 & 0.95 \\
& sucrose & 43.8 & -0.14 & 0.92 \\
& glucose & 20.9 & -0.12 & 0.85 \\
WHXWJ & starch & 17.8 & -0.11 & 0.75 \\
& s. carboh. & 47.0 & -0.12 & 0.92 \\
& sucrose & 47.0 & -0.15 & 0.90 \\
& glucose & 68.7 & -0.23 & 0.88 \\
\hline
\end{tabular}

non-structural dry matter as calculated by the model? Table $V$ shows the values of parameters calculated from equations (3) and (5).

The differences between $P\left(M n s_{r}\right)$, calculated from the model, and $P(G)$, directly measured, are not significant for both genotypes. Thus, the initial hypothesis can be neither rejected nor confirmed. The values of $\mathrm{P}\left(\mathrm{M} n s_{r}\right)_{T}$ are very uncertain since they were the result of complex calculations made from data obtained from
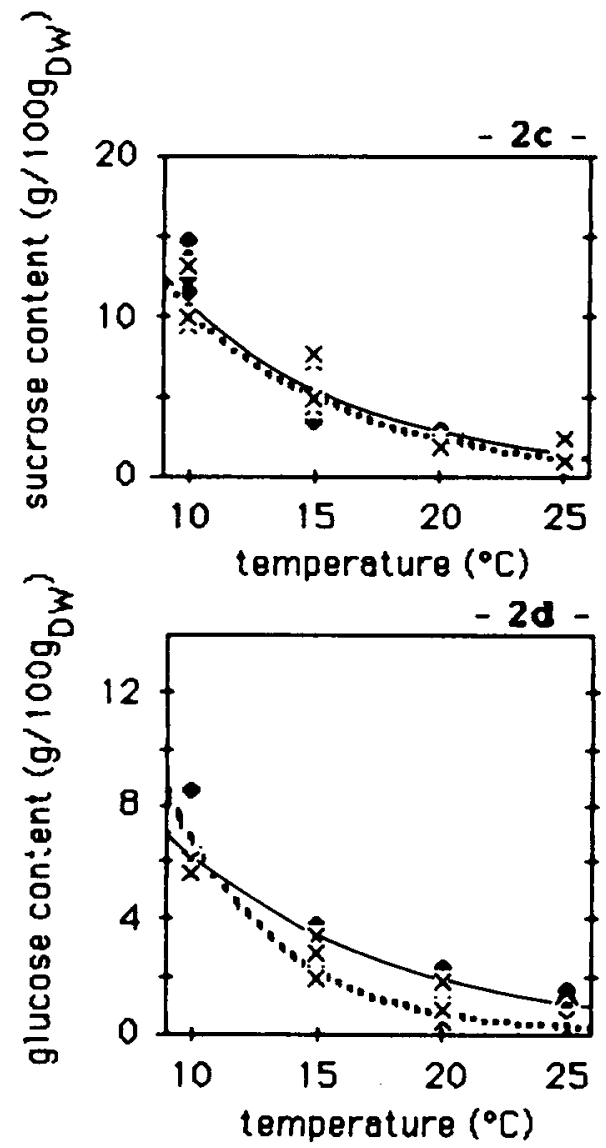
Table V. Means of relative (to $20^{\circ} \mathrm{C}$ ) carbohydrate content and calculated non structural dry matter accumulation in the roots for F7xF2 and WHXWJ (95\% confidence interval).

\begin{tabular}{|c|c|c|c|c|c|}
\hline \multirow[t]{2}{*}{ Genotype } & \multirow[t]{2}{*}{ Variables } & \multicolumn{4}{|c|}{ Root temperature } \\
\hline & & $10^{\circ} \mathrm{C}$ & $15^{\circ} \mathrm{C}$ & $20^{\circ} \mathrm{C}$ & $25^{\circ} \mathrm{C}$ \\
\hline \multirow[t]{2}{*}{ F7xF2 } & $\mathrm{P}\left(\mathrm{M} n s_{r}\right)$ & $0.15 \pm 0.09$ & $0.02 \pm 0.21$ & 0 & 0 \\
\hline & $P(G)$ & $0.25 \pm 0.07$ & $0.09 \pm 0.06$ & 0 & 0 \\
\hline \multirow[t]{2}{*}{ WHXWJ } & $\mathrm{P}\left(\mathrm{M} n s_{r}\right)$ & $0.39 \pm 0.13$ & $0.14 \pm 0.23$ & 0 & 0 \\
\hline & $P(G)$ & $0.23 \pm 0.08$ & $0.09 \pm 0.10$ & 0 & 0 \\
\hline
\end{tabular}

different plants (at present, it is impossible to make successive non-destructive measurements of the increase in dry matter). Values of $P(G)_{15}$ are also uncertain because of the intrinsic variability that still remained even though the experiments were made with $\mathrm{F} 1$ hybrids in highly controlled conditions.

What, then, is the value of our model?

- it is probable that the hypotheses are correct. These hypotheses and the results presented above agree with those generally acknowledged by different authors (as reviewed by Bourdu, 1984). However, since input numerical values are uncertain because of methodological constraints and intrinsic variability, there is considerable uncertainty about the output values.

\section{CONCLUSION}

When root temperatures are low for a short period, there is a considerable accumulation of carbohydrates in roots and shoots, similar to those observed by Grobbelaar (1963) for 10-dayold plants with 8 days or 20 days of temperature treatment and by Kleinendorst \& Brouwer (1970) for older plants. In the absence of additional results, it would seem that low root temperatures produced a complete over load of the root sinks and transfer pathways. This overload increased starch content in leaves, particularly in the sensitive genotype. The study of the effect of low root temperatures on the roots must therefore deal with the whole plant and not simply the root.

Uncertainties about the input parameters of the model of available energy in the roots are such that it is not possible to come to any precise conclusion about the biochemical nature of the accumulation of dry matter observed at low temperature.

This study shows that, at early growth stage, low root temperature quickly produces considerable carbohydrate accumulation in the whole maize plant. In natural conditions, maize is often exposed to low temperatures at this stage. This accumulation could therefore take place but it may be only a temporary traumatism that disappears once temperature conditions return to normal.

It could be of interest to study the same parameters in plants during temperature treatment recovery. The plant may be able to use the carbohydrates accumulated at low temperature to pass throughout a period of recuperation without suffering too much damage; during this period, assimilation rate can be greatly affected, particularly in sensitive genotypes (Stamp, 1987).

\section{REFERENCES}

Bourdu R. (1984) Bases physiologiques de l'action des températures. In : Physiologie du Maïs. Colloque de Royan, 15-17 mars 1983, INRA, 389-423

Crawford R.M.M. \& Huxter T.J. (1977) Root growth and carbohydrate metabolism at low temperatures. $J$. Exp. Bot. 28, 917-925

Frossard J.S. (1985) Effet de la température des racines sur leur respiration et sur la croissance des plantules de deux hybrides de maïs. Agronomie 5, 719-725

Frossard J.S. (1986) Essai de modélisation de l'utilisation de l'énergie dans les racines. Application à l'effet de la température racinaire chez des plantules de deux hybrides de maïs. Agronomie 6, 401-408

Gary C. (1988) Relation entre température, teneur en glucides et respiration de la plante entière chez la tomate en phase végétative. Agronomie 8, 419-424

Grobbelaar W.P. (1963) Response of young maize plants to root temperatures. Meded. Landbouwhogesch. Wageningen, 63, 1-71

Halhoul M.N. \& Kleinberg (1972) Differential determination of glucose and fructose, and glucose and fructose - yelding substances with anthrone. Anal. Biochem. 50, 337-343

Jourdan J. (1980) Variations Saisonnières de la Morphogenèse de la Croissance des Systèmes Aériens et Souterrains chez le Peuplier; leurs 
Relations avec les Glucides et les Transferts Minéraux. Thèse Doctorat es Sci. Université Grenoble, $159 p+$ annexes

Kleinendorst A. \& Brouwer R. (1970) The effect of temperature of the root medium and of the growing point of the shoot on growth, water content and sugar content of maize leaves. Neth. J. Agric. Sci. 18, 140148

McCree K.J. (1974) Equations for the rate of dark respiration of white clover and grain sorghum, as functions of dry weight, photosynthetic rate, and temperature. Crop. Sci. 14, 509-514

Mercier C. \& Tollier M.T. (1982) Séparation et dosages des glucides et des amylases. In: Guide pratique d'analyses dans les industries des céréales (Godon B. et Loisel W. eds) Lavoisier-APRIA, 273-325

Moldau H. \& Sober J. (1981) Growth rate-reserve content relationship as influenced by irradiance, $\mathrm{CO}_{2}$ concentration, and temperature. Photosynth. Res. 1, 217-231
Prioul J.L. (1984) Transport et distribution des assimilats chez le maïs: mécanismes, rôle des facteurs externes. In : Physiologie du Maïs. Colloque de Royan, 15-17 mars 1983, INRA, 303-319

Stamp P. (1987) The expression of photosynthetic traits during and following severe chilling stress of European and tropical maize genotypes. Physiol. Plant. 71, 73-76

Szaniawski R.K. (1981) Growth and maintenance respiration of shoot and roots in scots pine seedings. Z. Pflanzenphysiol 101, 391-398

Thornley J.H.M. (1970) Respiration, growth and maintenance in plants. Nature 227, 304-305

Thornley J.H.M. (1977) Growth, maintenance and respiration: a re-interpretation. Ann. Bot. 41, 11971203

Thornley J.H.M. (1982) Interpretation of respiration coefficients. Ann. Bot. 49, 257-259 